\title{
Mechanisms of Inequality: \\ Unequal Access to Organizational Power and the Gender Wage Gap
}

by Mia Hultin and Ryszard Szulkin*

*The authors are equally responsible for this work. Please, direct correspondence to mia.hultin@ @ofi.su.se. 
We gratefully acknowledge valuable comments from our colleagues, mainly sociologists and economists at the Swedish Institute for social research (SOFI). Especially, we wish to thank Anders Björklund, Richard Breen, Magnus Bygren, Ann-Zofie Duvander, Robert Erikson, Johan Fritzell, Carl le Grand, Åsa Rosén, Lotta Stern, and Michael Tåhlin. This work was partly financed by grants from RALF and HSFR. 


\begin{abstract}
In this paper, it is argued that women's limited access to organizational power structures is a constituent part of the explanation of gender wage inequality. Multi-level analyses conducted on a comprehensive Swedish data set combining information on a large number of private sector employers and all their employees confirm that establishments' gender wage gaps are wider the stronger the male representation among organizational decision-makers, net of individuals' human capital and various organizational features relevant for wage setting. Theoretical explanations focus on gender unequal outcomes of i) general rules and policies decided at higher organizational levels, and ii) everyday decision-making and daily interaction between superiors and their subordinates. On basis of the empirical results, we conclude that gender wage inequality is to a substantial degree driven by everyday decision-making in organizations. It seems as if close supervisors' decisions and suggestions about wage rates, promotions, internal training et cetera are to some extent based on personal preferences, loyalties, and contacts that are not gender neutral.
\end{abstract}




\section{INTRODUCTION}

The sociological literature on labor markets has increasingly directed its attention towards the significance of organizations and employers in creation of gender inequality in job rewards (see Reskin, McBrier, and Kmec 1999 for a review). Some researchers have pointed out that studies of labor market inequality ought to take into consideration the role played by those actors who have direct influence over organizational procedures and policies, that is, managers and supervisors (Marini 1989, Baron 1991). However, empirical research has not yet put much effort into scrutinizing in what ways gender inequalities in access to organizational power influence gender wage differentials. In this paper, we argue that women's limited access to organizational power structures is a constituent part of the explanation of gender wage inequality. ${ }^{1}$ Using a comprehensive Swedish data set combining information on a large number of private sector employers and their whole body of employees in 1995, we investigate whether establishments' gender wage gaps are wider the stronger the male representation among organizational decision-makers.

Presumably, the scarcity of data combining detailed information on multiple workers in a large set of organizations is one of the reasons behind the conspicuous lack of studies addressing the question if and how gender differences in access to organizational power influence gender wage inequality. Recently, a U.S. employer-employee matched data set was used to analyze effects on wage differentials 
of sex segregation and racial segregation at the establishment level (Carrington and Troske 1998, Bayard et al. 1999). However, to the best of our knowledge, multi-worker and multi-establishment data sets have not yet been used for exploring the role of organizational decision-makers in processes creating and sustaining gender wage inequality. Shenhav and Haberfeld (1992) and Hultin and Szulkin (1999) have investigated a similar research problem, however not on the kind of data used in the current article. Shenhav and Haberfeld's study, based on data from 1972-1973 pertaining to establishments in the Detroit area, lacked direct measures of individuals' wages and of other individual-level characteristics like education and seniority. Instead, authors used aggregate information on occupational earnings and sex composition to calculate weighted sex earnings ratios at the establishment level. Their results indicated that gender differences in occupational earnings are more narrow the higher the proportion of female managers within the establishment. Hultin and Szulkin used a Swedish nationally representative data set including only one employee per establishment in 1991. The authors found that women who work in establishments in which relatively many of the managers and supervisors are men have lower wages than have women with similar qualifications and job requirements, but who work in establishments with larger proportions of women among decision-makers.

Given the extensive character of the employer-employee information that we have at our disposal, we can both overcome some of the problems built into the studies mentioned above and extend earlier research in several ways. First, we can 
estimate the effect on the gender wage gap of gender differentiated access to organizational power hierarchies net of individuals' human capital and certain relevant organizational features. Second, we can, at least to some extent, deal with the potential objection that an empirical outcome confirming our main assumption is contaminated by sorting processes implying that some organizations for some reasons attract and retain female - or male - employees with especially high productive capacities. Third, we are able to analyze at which specific organizational authority level the studied discriminatory process is mainly generated.

\section{B RING THE BOSSES AND THEIR UNDERLINGS IN! ${ }^{2}$}

Around two decades ago, Baron and Bielby urged social scientists studying labor market stratification to "bring the firm back in" (Baron and Bielby 1980: 738). Yet, much theoretical and empirical work still needs to be done in order to reveal in what ways circumstances within establishments influence workers' chances and rewards (c.f. Reskin, McBrier, and Kmec 1999), and how ascriptive characteristics like gender become important lines of cleavages in distributive conflicts over scarce rewards within organizations.

Analysts within the field of organizational demography have stressed that processes generating inequality should be investigated in terms of the numerical strength of various demographic categories within organizations (Pfeffer and DavisBlake 1987, Pfeffer 1989). Various social and demographic groups within work 
organizations take an interest either in initiating and sustaining or in undermining and abolishing ascriptive considerations in reward distribution processes (Baron 1991, Tomaskovic-Devey 1993). According to the minority power argument, a subordinate or minority group's power grows with its proportion of the total stock of labor within an organization (c.f. Pfeffer 1989, see also Kanter 1977). However, this strong version of the minority power argument is contradicted by results from a number of empirical studies on gender inequality, showing that both women and men's rewards are relatively low in organizational milieus in which many women work (e.g. Groshen 1991a, Carrington and Troske 1998). ${ }^{3}$

As proposed by, for example, Shenhav and Haberfeld (1992), one should distinguish between a group's size in general and its representation in positions of power in particular. In order for a certain group, however large, to be able to state its claims and prosper in reward distribution processes, it needs to have at its disposal the strength emanating from representation in strata endowed with decision-making power (see also Cohen, Broschak, and Haveman 1998). This argument is also of central importance for feminist perspectives in which it is claimed that unwarranted gender differences in rewards arise primarily due to men's desire and ability to preserve their advantages in distributional processes (e.g. Reskin 1988, Acker 1992). One important prerequisite for this ability ought reasonably be organizational power in terms of command over rules and procedures that may serve the purpose of distributing valued resources in favor of the favored. 
Below, we elaborate two potential explanations to why the gender wage gap is wider the stronger the male representation among organizational decision-makers.

The first explanation is primarily based on the idea that the gender wage gap within organizations is in part a result of general rules and policies decided at higher hierarchical levels. The second explanation above all involves everyday decision-making and daily interactions between superiors and their underlings. 
Organizational decision-makers and gender wage inequality

The way in which general organizational rules and policies are designed may render inequality in opportunity between different groups of workers. It has been claimed that ascriptive gender stereotypes embedded in organizational structures contribute to unequal reward distribution in the labor market (e.g. Baron 1991). Hence, organizational policies and procedures may entail negative consequences for women as a group, irrespective of individual women's capabilities and preferences. For instance, allocation processes within firms are to some extent influenced by stereotyped beliefs on what constitutes "women's jobs" and "men's jobs" (Milkman 1987, Reskin and Padavic 1988). Bielby and Baron's prominent empirical research on sex segregation in the labor market has indicated that employers tend to reserve some jobs for men and some jobs for women (e.g. Bielby and Baron 1986).

Examples from the literature witness that positions mainly filled by women tend to be excluded from lucrative internal labor market arrangements, even in establishments with an otherwise high potential for career advancement. le Grand, Szulkin, and Tåhlin (1994) showed that male employees in internal labor markets face a relatively steep seniority wage profile, while this effect is absent for female employees. DiPrete and Soule (1988) found that women's internal job ladders compared to men's in general are shorter and more seldom reach over higher-level barriers. Such gendered promotion structures quite evidently conve y gender wage inequality, since wage growth is often brought about by upward shifts of positions. 
The fact that men and women rarely share job positions implies a scope for employers' devaluation of work that is predominantly performed by women, although the value of this work resembles that of predominantly male tasks. This kind of discrimination is often referred to as comparable worth discrimination (Treiman and Hartmann 1981). Once gender differentiated mobility schemas or pay rates are set, the normal functioning of the organization - or "business as usual" - tends to maintain the status quo and continues to ensure further inequality in reward systems (c.f. Blau, Ferber, and Winkler 1998). Research shows that the gender structure of existing ordinal ranking of jobs in organizations' pay systems tends to be very resistant to change and is seldom subject to transposition (c.f. Acker 1989; 1990, Kim 1989). Hence, both sex labeling of jobs and relative pay rates within organizations show a good portion of inertia once established (Bielby and Baron 1986).

Power over general organizational policies is an important tool for creating, sustaining, and modifying allocation routines and reward structures within establishments. There are reasons to believe that female and male managers tend to use their decision-making power differently, in ways that in turn may render substantial consequences for women's relative wages within work organizations. Reasonably, female managers are less prone than their male counterparts to allocate in a routine manner women to typically female jobs. Also, female decision-makers should be more apt to extend promotion opportunities for positions predominantly filled by women, for instance by creating "bridge" positions through which employees can switch ladders 
more easily (Reskin and Padavic 1994). Furthermore, female decision-makers are presumably more attentive than their male counterparts in terms of observing and valuing typically female work, thereby minimizing comparable worth discrimination. 
Empirical research supports the notion that female managers in general are less inclined than their male counterparts to initiate and sustain institutionalized gender discriminatory practices. For example, establishments with relatively many female managers are less sex segregated than otherwise comparable establishments (Baron 1991, Baron, Mittman, and Newman 1991, Cohen, Broschak, and Haveman 1998). Furthermore, female decision-makers have been found to be more prone than their male confrères to take an active part in measures aimed at establishing employment equity at the workplace (Baron 1991). Female leaders are presumably also more willing than their male counterparts to adjust work arrangements so that they become more compatible with women's in general extensive family responsibilities, for example by allowing flexible working hours and by keeping overtime work and inconvenient working hours to a minimum.

We argue that organizational decision-makers have influence over how general systems of opportunity are designed within establishments and that the sex composition among these actors in turn influences the advancement and reward chances for women as a group. In work organizations in which there are no or only a few women in power positions, gender may go on being a prominent category that implies negative consequences for women placed in lower organizational strata (c.f. Ely 1995, Cohen, Broschak, and Haveman 1998).

It takes two to tango: an interaction perspective on gender wage inequality 
Decision-making in organizations does not revolve around general rules and procedures only, however. Also accounted for existing systems of opportunity within establishments, people in authority positions directly influence who will get ahead in the reward distribution by making decisions and giving suggestions about individual subordinates' wages. In the previous section, we argued that gender bias may influence the design and perpetuation of within-firm systems of allocation and wage setting decided at high organizational levels. But individual employees' success in these opportunity structures is also, at least in part, governed by daily decisions made by people in charge. Managers' and supervisors' power over reward allocation can also be manifested outside the actual wage-setting process. Employees' chances for internal career mobility and selection of individuals to more qualified positions, to training programs et cetera are, at least in part, governed by daily decisions made by organizational superiors. To the extent that minor everyday decisions concerning individual employees' opportunities are systematically gender biased, they generate gender inequality in outcome in the long run.

The hitherto attention devoted to the deeds of organizational decisionmakers gives us only at most half of the picture of organizational actors' impact on reward distribution processes. It has been argued that systems of advantage and disadvantage are embedded in everyday interactions between superordinate and subordinate groups (Bielby 1987). Bridges (1989) claims that wage setting processes in work organizations are characterized by continuous interactions and negotiations 
between organizational actors who represent different interests (see also Acker 1991). Hence, it seems called for to pay attention also to female and male supervisees' opportunities to mobilize power resources in work organizations. Some arguments and results originating from the social network approach are relevant in this context. There is strong evidence that essential resources are embedded in social networks and that access to networks promotes favorable outcomes in reward allocation processes (see Lin 1999 for a review). Empirical studies show that social relations affect income attainment (Bridges and Villemez 1986, Boxman, De Graaf, and Flap 1991, Simon and Warner 1992) and chances for upward mobility (Burt 1995). Social networks in work organizations also offer informal support systems (Blau, Ferber, and Winkler 1998) that in turn may enhance employees' reward opportunities.

The social network literature has furthermore demonstrated the impact of demographic and social criteria like sex and ethnicity on the occurrence of social contacts and on individuals' centrality in networks. According to the similarity attraction paradigm (Byrne 1971, see also Tajfel 1982), closer social ties primarily emerge among people with similar basic characteristics. Social similarity tends to evoke attraction and acts as a mechanism for resolving uncertainty (c.f. Pfeffer 1989, Reskin and McBrier 2000). Social proximity to those actors who occupy central network positions enhances individuals' or groups' exchange opportunities and thus strengthen their bargaining power in reward distribution processes (c.f. Granovetter 1988, Hedström, forthcoming). For instance, when there is ambiguity as regards who is the most suitable candidate for a 
certain vacant position, decision-makers tend to minimize risk by choosing the person who is most socially similar to them (Pfeffer and Salancik 1978).

In concordance with the similarity attraction paradigm, it has been found that both men and women tend to interact within sex-segregated networks in organizations (McPherson and Smith-Lovin 1987). There are good reasons to believe that superiors' minor everyday decisions on who will benefit in reward distribution processes and who will obtain access to career opportunities are influenced by interaction in social networks. Given the sex segregated nature of professional networks, it seems reasonable to assume that individual female supervisees face greater reward opportunities and receive more support for their claims in workplaces where the female representation in central positions, i.e., among decision-makers, is relatively high.

\section{WAGE SETTING PROCESSES IN SWEDEN}

There are reasons to believe that the impact of organizational characteristics on earnings is smaller in Sweden than in many other Western countries. When analyzing the specific features of the Swedish labor market, observers have emphasized the high degree of institutionalization and regulation (Edin and Holmlund 1995, Edin and Topel 1997). The most prominent feature mentioned in this context is that wages from the mid 1950s to the early 1980s were determined to a large extent through centralized collective bargaining at the national level. A solidaristic wage policy aiming at equal pay for equal 
work, regardless of the profitability and productivity of the firm or industry, has been widely pursued. This policy had the explicit purpose of minimizing wage variation between equal jobs across firms and sectors. The very high union coverage rate in Sweden in combination with a well organized and, until recently, highly centralized confederation of employers facilitated implementation of a solidarity wage policy. This policy resulted in a decrease of the overall wage dispersion in the Swedish labor market (Hibbs 1991).

Recent studies have demonstrated that centralized wage bargaining produces relatively small wage inequalities in general (Barth and Zweimüller 1995, Blau and Kahn 1996, Elliott and Bender 1997) and small gender wage differentials in particular (Hammond and Harbridge 1995). The centralized wage bargaining process in Sweden, with the aim of raising the relative wages of low-wage workers, may indirectly have resulted in a relatively small wage gap between women and men. Empirical findings from international comparisons show that a society's overall wage inequality is positively related to the gender wage gap. The Swedish labor market is characterized by relatively low wage dispersion and, hence, comparatively small wage differentials between women and men (Rosenfeld and Kalleberg 1990, Blau and Kahn 1992). However, even during the regime of centralized bargaining, a far from negligible adjustment of wages occurred at the firm level in the form of wage drift.

Thus, the scope for wage dispersion across and within firms for similar kinds of jobs was relatively limited in Sweden until the beginning of the 1980s. Since 
then, consensus around the solidarity wage policy has been undermined. The national confederation of employers has adopted new policies aimed at determining wages at the firm level, while the trade unions' attitudes towards such decentralization have been mixed. This new situation has resulted in a decentralization of wage negotiations, which has given more latitude for local agreements. Nevertheless, the egalitarian character of wage formation in Sweden is still relatively strong by international standards. In sum, the assumption here is that the scope for wage discrimination against women in the Swedish labor market is comparatively small, but still remains. The impact of discriminatory practices applied at the level of the firm as revealed by our analysis of Swedish data may accordingly be viewed as a conservative estimate of their importance in other Western labor markets. 


\section{SAMPLE}

In the empirical analyses in this paper, we combine information on employers and employees in a large number of Swedish private sector organizations. The data set has its origin in the 1991 Swedish Establishment Survey, a national probability sample of 2135 private and public sector employers. ${ }^{4}$ Information pertaining to all employees in these organizations in 1995 has been collected from a variety of registers. The crucial independent variable is the sex composition of establishments' managerial and supervisory staff. Since data on individuals' position in the organizations' hierarchical structures are only available for the private sector, public sector organizations have been excluded from the sample. There are 593 private organizations in the Swedish Establishment Survey sample for which there is accessible information on employees' position in the organizational hierarchical structure and in which both men and women work. For reasons discussed below, we perform separate analyses for white-collar and blue-collar employees. The number of organizations studied is 317 for blue-collar employees. These organizations together employ 82190 blue-collar workers. Correspondingly, we include 546 organizations that employ 74960 white-collar workers. 290 of all studied organizations employ both blue-collar and white-collar workers. 


\section{VARIABLES AND ANALYTICAL STRATEGY}

The variables in the analyses are both on an individual and on an organizational level. Individuals' earnings are measured as the logarithm of monthly full-time equivalent pretax earnings. The data sources for individual earnings are registers from the Swedish Employers Confederation, the Swedish Trade Union Organization, and Statistics Sweden. Individuals' education refers to the total number of years of formal schooling. For employees who finished their secondary education after 1972, we have information on the grade point average from this education. Seniority measures the number of years that the employee has worked in the establishment. This variable is left-censored, since data are only available from 1986 onwards. The source of data on education and seniority is Statistics Sweden. Labor market experience is an indirect measure of the number of years that the individual has been in employment, estimated through records of old-age pensions credits from the Swedish National Insurance Board. The experience variable represents the number of years from 1960 onwards during which the employee has had an income qualifying for old-age pension. ${ }^{6}$ To take curvilinear effects into account, we include a square term of experience in the analyses.

The information on whether employees hold a white-collar or a blue-collar occupation has been derived from the wage registers mentioned above. Data on skill level of jobs are available for white-collar occupations only. A trisect variable indicating the normal skill required for a given job was derived from the International Standard Classification of Occupations (ISCO-88). For the first category of jobs, a first-level 
secondary education is required. The second skill category includes jobs that require post-secondary education. Finally, we distinguish jobs that demand a university degree. Information on jobs' skill levels was obtained from the Swedish Employers Confederation.

The natural logarithm of the number of employees in the establishment, the proportion of women among blue-collar and white-collar employees, respectively, and organizations' industry are all variables on the organizational level. ${ }^{6}$ The data source for these variables is Statistics Sweden. The crucial variable at the organizational level is the proportion of male managers and supervisors of all managers and supervisors in the establishment. Employees who have as their full-time responsibility to guide others' work are classified as managers or supervisors. On the basis of ISCO- 88 occupational codes together with additional data from the Swedish Employers Confederation, we are able to distinguish between managers and supervisors, that is, between decision-makers at higher and at lower hierarchical levels. Accordingly, we can calculate the total proportion of male decision-makers in the establishment as well as the proportion of male managers and male supervisors, respectively.

It is important to note that the variable measuring the proportion of male managers and supervisors is highly skewed. Table A1 in Appendix gives descriptive statistics for blue-collar workers and the establishments that employ them. The average proportion of male managers and supervisors in the blue-collar sample is 0.89 . In 148 establishments of 317 , there are no female managers or supervisors at all. In 4 
establishments, there are no male decision-makers. Descriptive statistics for whitecollar workers and their establishments are given in Table A2 in Appendix. The average proportion of male managers and supervisors in the white-collar sample is 0.87 . In 285 establishments of 546, there are no female decision-makers at all. The number of whitecollar establishments with no male decision-makers is 12 . Male decision-makers are concentrated to relatively large organizations, to organizations with low proportions of female employees, and to industries such as manufacturing and construction. Thus, high proportions of male managers and supervisors tend to be found in labor market locations characterized by relatively high wages. Consequently, we expect to find a positive main effect on organizations' mean wage levels of the proportion of male managers and supervisors. However, our assumption is that this association is not of a causal nature, but rather brought about by certain organizational characteristics that we are in part able to control for. Hence, we take it that the proportion of male managers and supervisors does not per se increase organizational wage levels. The causal question at hand is instead whether the gender wage gap is wider in organizations with many male decisionmakers than in other organizations, given organizational mean wage levels.

The data set is made up by information both on individual employees and on the organizations in which they work. The appropriate statistical method for dealing with information of such a hierarchical kind, with individual employees nested in work organizations, is multilevel modeling (Bryk and Raudenbush 1992). Multilevel models estimate within-organizational and between-organizational equations simultaneously, 
accounting for potential dependence between observations within organizations. The formal representation of the estimated models is given below.

Level-1, within-organizational model:

$\operatorname{lnwage}_{\mathrm{ij}}=\mathrm{B}_{0 \mathrm{j}}+\mathrm{B}_{1 \mathrm{j}} * \mathrm{WOM}_{\mathrm{ij}}+\mathrm{B}_{2} * \mathrm{EXP}_{\mathrm{ij}}+\mathrm{B}_{3} * \mathrm{EXPSQ}_{\mathrm{ij}}+\mathrm{B}_{4} * \mathrm{SEN}_{\mathrm{ij}}+\mathrm{B}_{5} * \mathrm{EDUC}_{\mathrm{ij}}+\mathrm{R}_{\mathrm{ij}}$

(Equation 1)

The level-1 model, or within-organizational model, estimates individual wages within each organization. $B_{0 j}$ is the intercept for organization $j$ and $B_{1 j}$ represents the gender wage gap for organization $\mathrm{j}$. Thus, both the intercept and the estimate for the gender wage gap are allowed to vary between organizations. $\mathrm{B}_{2}$ through $\mathrm{B}_{5}$ are fixed parameters for employees' human capital and are not allowed to vary between establishments. All fixed parameters are centered around their grand means. $R_{i j}$ is the level-1 random variance, or each individual's unique contribution to the outcome. The random variance is assumed to be normally distributed. 
Level-2, between-organizational model:

$\mathrm{B}_{0 \mathrm{j}}=\mathrm{G}_{00}+\mathrm{G}_{01} *$ PROPMALEBOSS $_{\mathrm{j}}+\mathrm{U}_{0 \mathrm{j}}$

(Equation

2)

$\mathrm{B}_{1 \mathrm{j}}=\mathrm{Gi} 0+\mathrm{Gi} 1 *$ PROPMALEBOSS $\mathrm{j}+\mathrm{U}_{\mathrm{ij}}$

(Equation

3)

The level-2 model, or between-organizational model, is built up by two separate equations. Equation 2 estimates organizational wage levels, or more formally, the variation between organizations in intercepts $\left(B_{0 j}\right) . G_{00}$ represents the average wage level in organizations in which there are no male managers and supervisors, $G_{01}$ is the regression coefficient for the effect of the proportion of male managers and supervisors on the organizational wage level, and $\mathrm{U}_{0 \mathrm{j}}$ is the random variation in wage levels between establishments. In equation 3 , the gender wage gap $\left(B_{1 j}\right)$ is the outcome. $G_{10}$ is the average gender wage gap in organizations in which there are no male managers and supervisors, $G_{11}$ is the regression coefficient for the effect of the proportion of male managers and supervisors on the gender wage gap, and $U_{1 \mathrm{j}}$ is the random variation between establishments in gender wage gaps.

Our primary interest is to explore the influence on the gender wage gap of the sex composition of establishments' managerial and supervisory staff, net of individuals' human capital and certain organizational features relevant for reward allocation processes. We perform the analyses separately for blue-collar and whitecollar employees, since there are reasons to believe that wage setting processes differ 
between these two categories of employees. Moreover, the earnings data for blue-collar and white-collar employees have been collected from different sources. The empirical analyses are conducted only for those male and female employees who lack managerial or supervisory responsibilities themselves.

In the first stage of the analysis, we estimate the effect on the gender wage gap of the proportion of male managers and supervisors, net of human capital (that is, $\mathrm{G}_{11}$ in the level-2 model defined in equation 3 above) for blue-collar and white-collar employees, respectively. In additional models, we let organizational size, the proportion of female employees in the establishment, and industry have an impact on organizational wage levels. ${ }^{7}$ The rationale for this alternative model specification is that wages tend to be relatively low in smaller establishments and in establishments with relatively high proportions of female employees, and that wage-levels vary by industry.

In the next analytical stage, we deal with the possible objection that an observed relationship between the proportion of male decision-makers and the gender wage gap is generated by unmeasured selection processes, meaning that particularly talented workers are allocated to certain establishments. Ability-sorting processes have been extensively discussed by labor economists as one explanation of wage differences (e.g. Groshen 1991b). In our case, ability sorting processes would imply that some organizations for some reasons attract and retain female- or male-workers with especially high productive capacity. Thus, these organizations would eventually be imprinted both by relatively high proportions of women in decision-making positions 
and by relatively high wages for female supervisees. The data set makes it possible to consider the influence on the outcome of potential selection processes of this kind. For employees who finished their secondary education after 1972, we have information on the grade point average from this education. To the extent that ability-sorting processes influence the effect of the sex composition among decision-makers on the gender wage gap in organizations, the relationship should be substantially reduced when secondary school results are included in the equations. ${ }^{8}$

In a final analytical stage, we examine more thoroughly the role played by managers and supervisors in wage setting processes in organizations. Our main assumption is that the gender wage gap is wider in organizations in which there are relatively many male managers and supervisors. This assumption is in turn based on the straightforward premise that people in authority positions influence employees' wages either in a direct way by making decisions and giving suggestions about subordinates' wage rates, or indirectly by influencing selection of employees to potentially lucrative career slots et cetera. However, all decision-makers do not decide about all employees' rewards. The Swedish Employers Confederation's definition of a supervisor is a person carrying out full-time responsibility for work conducted by blue-collar employees. By this definition, supervisors do not exert influence over white-collar employees' wages. Accordingly, an observed significant relationship between the sex composition among supervisors and the gender wage gap for white-collar workers would seriously question the validity of our measures of hierarchical authority. For blue-collar workers, however, 
both managers and supervisors potentially play a substantial role in the wage determination process. In this case, an assessment of at which hierarchical level the analyzed discrimination process mainly takes place enables us to empirically evaluate the two main theoretical arguments distinguishing between consequences for reward allocation of general policy making and of daily decisions, respectively. 


\section{RESULTS}

General models of the effect on the gender gap

of the proportion of male managers and supervisors

Table 1 gives results from six hierarchical linear models (HLM), estimating the effect of the sex composition in organizational power structures on gender wage gaps in organizations. Models 1 to 3 are estimated for blue-collar employees and Models 4 to 6 are estimated for white-collar employees. Models 1 and 4 are baseline models that give the variance between establishments in gender wage gaps, given employees' human capital. In Models 2 and 5, the proportion of male managers and supervisors is included as predictor. In Models 3 and 6, establishment size, the proportion of female blue-collar and white-collar employees in the establishment, and industry are added to the secondlevel equation for organizational wage levels. This means that these variables are allowed to influence organizational wage levels (i.e., the intercept in the equation).

[Table 1 around here]

Models 1 and 4 in Table 1 show that the average gender wage gap, as well as the variance in gender wage gaps between organizations, is more than twice as large for white-collar as for blue-collar employees, given employees' human capital. ' In Models 2 and 5, it is shown that the effect of the proportion of male managers and supervisors on the gender wage gap is negative and significant, which means that the gender wage gap is wider in 
establishments with higher proportions of male decision-makers. The connection between the proportion of male decision-makers and the gender wage gap seems to be of about the same magnitude for blue-collar and white-collar employees. For blue-collar employees, the average gender wage gap in establishments with no male managers and supervisors $\left(\mathrm{G}_{10}\right)$ is approximately zero. The corresponding figure for white-collar employees is about -0.07 . The estimated effect on the gender gap of the proportion of male decision-makers $\left(\mathrm{G}_{11}\right)$ is about -0.11 for both blue-collar and white-collar workers. The inclusion of the proportion of male decision-makers reduces the betweenestablishment variance in gender wage gaps with about 8 percent for blue-collar employees and 10 percent for white-collar employees. We obtained these values through subtracting from $1 \mathrm{U}_{1 \mathrm{j}}$ in Model 2 divided by $\mathrm{U}_{1 \mathrm{j}}$ in Model 1, and $\mathrm{U}_{1 \mathrm{j}}$ in Model 5 divided by $\mathrm{U}_{1 \mathrm{j}}$ in Model 4, respectively. ${ }^{10}$

One should notice that there is a strong positive main effect of the proportion of male managers and supervisors on organizational mean wage levels for blue-collar employees (Model 2 in Table 1). For white-collar workers, this effect is of considerably lower magnitude and does not meet conventional requirements for statistical significance. Thus, the analyses have so far supported the assumption that women's relative wages are pressed down in establishments with relatively many male decision-makers, but the effect is partly moderated by the condition that wage levels are relatively high in establishments in which there is a strong representation of men in the power structures. This is especially true for blue-collar employees. 
As mentioned above, our expectation is that the positive main effect of the proportion of male managers and supervisors on mean wage levels should disappear, or at least diminish, when other organizational characteristics relevant for average wage levels are controlled for. This expectation holds as far as blue-collar employees are concerned. A comparison between Models 2 and 3 in Table 1 shows that the relatively strong positive main effect of the proportion of male managers and supervisors on mean wages becomes substantially reduced and statistically insignificant when organizational size, proportion of female employees, and industry are controlled for (Model 3). Controlling for these organizational characteristics does not influence the positive main effect of the proportion of male decision-makers on mean wage levels for white-collar workers. The main effect is practically of the same magnitude in Model 5 and Model 6 and remains just below the significance requirements. Furthermore, the association between the proportion of male decision-makers and organizational gender wage gaps remains almost unchanged for both blue-collar and white-collar workers after organizational characteristics are accounted for (Models 3 and 6). Thus, the detrimental influence of men's representation among managers and supervisors on women's relative wages exists net of organizational s ize, proportion of female employees, and industry. ${ }^{11}$

In order to validate further the results, we performed a number of additional analyses. First, we allowed the fixed parameters for employees' human capital in the level-1 model to vary across establishments. ${ }^{12}$ The results from this analysis (not shown) indicated that the effects of human capital on earnings exhibit significant variation 
between establishments. More interesting given the focal question in this study, however, is that the relationship between the proportion of male decision-makers and the wage gap remained unaltered with this model specification (i.e., compared to the results given in Model 3 and Model 6 in Table 1). Second, we estimated the potential influence on the crucial relationship of the level of skill by adding jobs' skill requirements to the level-1 equation for white-collar employees (results shown in Table A3 in Appendix). Controlling for skill level reduced the effect of the proportion of male managers and supervisors both on the gender wage gap and on organizational mean wage levels. However, the effect on the gender gap remained strong, indicating that the proportion of male decision-makers in establishments influences the gender wage gap also accounted for the process by which equally educated and experienced male and female white-collar employees are sorted to job positions with different skill requirements.

Furthermore, we examined the possibility of nonlinear effects of the proportion of male decision-makers on the gender wage gap. In order to allow for a curvilinear relationship, we categorized the original interval measure of the proportion of male managers and supervisors into three dummy variables. The first category included establishments with 0 to 67 percent male decision-makers, the second category included establishments with 68 to 99 percent male decision-makers, and the third category consisted of establishments with an all-male management. An analysis including this trisect classification (results not shown) rendered results that were in 
essence the same as those given by the analyses in which the interval sex composition variable was used. In a final extension of the analysis, we examined whether the crucial relationship could be driven by relatively small establishments with very few employees of each sex. An analysis performed on a sample of organizations with at least ten whitecollar or blue-collar workers of each sex confirmed the findings given in Table 1.

The results presented in this section strongly indicate that the sex composition in power structures within organizations has a substantial influence on the gender wage gap. The relationship seems straightforward for both blue-collar and whitecollar employees. We have seen that some of the models reveal positive main effects of the proportion of male managers and supervisors on organizational wage levels.

However, these effects are - at least after controls for organizational characteristics related to mean wage levels - relatively weak and insignificant, indicating that female employees in general benefit from working in establishments with a relatively strong female representation among managers and supervisors. In the next section, we elaborate the analyses further in order to deal with the possibility that the findings are contaminated with bias due to ability sorting processes.

\section{Accounting for potential ability selection bias}

Table 2 provides results from analyses in which we examined potential influence of ability sorting bias by accounting for employees' grade point average from secondary school. However, the strategy with including average grades in the models reduces one 
kind of selection bias, simultaneously introducing another. Data on grade point average are available only for employees who finished their secondary education after 1972. Hence, the organizations for which we are able to test the influence of ability sorting processes are characterized by a relatively low average age among employees. The exclusion of older employees means that the analyses including average grades are conducted for a subsample of about 50 fewer organizations and 50000 fewer employees compared to the full blue-collar sample, and 100 fewer organizations and 45000 fewer employees compared to the full white-collar sample. ${ }^{13}$

The fact that the subsamples analyzed in Table 2 are substantially reduced compared to the full samples analyzed in Table 1 calls for a thorough investigation of the effect of the proportion of male decision-makers on the gender wage gap. Model 1 (blue-collar workers) and Model 3 (white-collar workers) in Table 2 include the same predictors as the full sample models (Models 3 and 6 in Table 1). Average grades are added in Model 2 (blue-collar workers) and Model 4 (white-collar workers) in Table 2. For blue-collar workers, the impact of the proportion of male managers and supervisors on the gender wage gap is somewhat weaker in the subsample compared to in the full sample (compare the estimates in Model 1 in Table 2 with those in Model 3 in Table 1). The essential relationship remains practically unaltered when average grades are included in the individual equation for blue-collar employees (Model 2 in Table 2). Thus, as far as blue-collar workers are concerned, the effect of ability sorting processes 
does not dismantle the support for the main assumption that restricted female access to organizational power structures has a detrimental effect on women's relative wages.

[Table 2 around here]

For white-collar employees, the impact of the proportion of male decision-makers on the gender wage gap is reduced by more than a half in the subsample as compared to in the full sample (compare the estimates in Model 3 in Table 2 with those in Model 6 in Table 1). When average grades are included in the individual equation for white-collar employees (Model 4 in Table 2), it turns out that the influence of the proportion of male managers and supervisors on the gender wage gap is only marginally reduced. The remaining effect on the wage gap is statistically significant also with this model specification. Thus, the influence on the crucial relationship of ability sorting processes seems to be relatively limited also for white-collar workers.

In sum, it seems as if ability sorting processes are not a hidden mechanism behind the observed finding showing that women's relative wages are depressed the more men are represented in organizational power structures. At the same time, the results presented in Table 2 indicate that the examined discrimination process is of a lower magnitude in the subsample than in the full sample. We can of course not completely rule out the objection that selection processes are involved in producing the observed relationship between the proportion of male decision-makers and the gender 
wage gap. However, the conducted test has provided good reasons to believe that the studied mechanism of discrimination is of substantial importance for processes generating gender wage differentials in the labor market.

\section{The role of decision-makers at different hierarchical levels}

In this section, we try to specify levels of authority at which gender inequality in financial rewards are generated and sustained. We do this by distinguishing between the role played by higher-level decision-makers (managers) and lower-level decisionmakers (supervisors), respectively, in the wage discrimination process. The analyses below include only those establishments for which there is information on the sex composition among both managers and supervisors. Again, the number of establishments analyzed becomes substantially reduced compared to the full sample. The main reason behind the sample reduction is that there by definition are no supervisors in organizations that employ white-collar employees only. In addition, the number of organizations becomes reduced due to the fact that some (mostly small) organizations with both white-collar and blue-collar employees have failed to report to the Swedish Employers Confederation the necessary information on individuals holding supervisory positions.

The results presented in Table 3 indicate that decision-makers at hierarchical levels relatively close to their subordinates are important actors in the processes generating gender wage differentials among supervisees. As can be seen from 
Model 1, the gender wage gap among blue-collar employees widens with the proportion of male supervisors, while the effect on the gap of the proportion of male managers is non-existing for this category of employees. Correspondingly, Model 2 shows that the gender wage gap is relatively wide for white-collar employees in organizations with a relatively strong male dominance among managers, while there is no effect on the gender gap of the proportion of male supervisors. One should also note that the main effects on average wage levels of the proportion of male managers and supervisors, respectively, are not significant in the analyses presented in Table 3 . This indicates that the discrimination process apparently dominates over the main effect of the proportion of male decision-makers on wages.

[Table 3 around here]

Our results have given support to the idea that organizational processes generating gender wage differentials can be traced mainly to those hierarchical levels at which daily interaction between subordinates and decision-makers takes place. However, we cannot rule out the possibility that also general decision-making contributes to gender inequality in reward distribution processes. In order to reach a more clear-cut conclusion for white-collar workers in this respect, we ought to be able to distinguish between managerial positions involving responsibility for general policies on the one hand, and responsibility for white-collar workers' daily work on the other hand. This kind 
of data is however not available. Thus, without rejecting the idea that general decisionmaking at high organizational levels may have an impact on gender wage inequality, we conclude that inequality is to a substantial degree driven by everyday decision-making in organizations. Close supervisors' decisions and suggestions about wage rates, promotions, internal training et cetera may, at least to some extent, be based on personal preferences, loyalties, and contacts that are not gender neutral. Such an interpretation seems reasonable in light of the results indicating that the sex composition among supervisors matters for the gender wage gap among blue-collar workers, whereas the sex composition among managers matters for the gender wage gap among white-collar workers.

\section{SUMMARY AND CONCLUSIONS}

The point of departure in the analyses presented in this paper was the idea that power relations in work organizations are of crucial importance for understanding how gender inequalities in financial rewards are generated and sustained in the labor market. If gender wage differentials are to be explained in terms of discrimination, employers and other decision-makers in work organizations ought reasonably to be important actors in the process leading to women obtaining inferior rewards for their performance in the labor market. Although a number of scholars have emphasized the potential role played by employers and other organizational decision-makers in processes generating gender inequality in the labor market, very few empirical studies have scrutinized in what ways 
gender-differentiated access to organizational power influences gender wage differentials.

Our analyses conducted on a comprehensive Swedish employer-employee matched data set covering a large number of private sector organizations and their employees clearly demonstrated that organizational gender wage gaps are wider the larger the representation of men among managers and supervisors, accounted for supervisees' human capital and for organizational size, industry, and overall sex composition. Analyses including average grades from secondary education pointed in the direction that the observed relationship between sex composition among decisionmakers and the gender wage gap cannot be explained in terms of ability selection processes. Clearly, women have particularly low relative wages in establishments in which there are no women or only a few women in positions of power. We believe that this finding supports the idea that the reward structure in the labor market to some extent reflects men and women's relative power within work organizations.

We have provided arguments from structural discrimination theories and the social network approach to why the sex composition among organizational decisionmakers matters for the size of the gender wage gap. According to the first argument, organizational decision-makers exert power over general policies and thus have the capacity to either initiate and sustain or to undermine institutionalized gender bias in reward distribution processes within organizations. It was argued that male organizational decision-makers are more inclined than their female counterparts to 
sustain gender bias in reward distribution processes, for example by allocating typically male jobs to internal labor markets and by leaving typically female jobs outside such potentially lucrative career arrangements. On the contrary, female managers are due to self-interest, solidarity or loyalty with other women reasonably more willing to set aside discriminatory policies. The second theoretical argument focuses on consequences for gender wage inequality of daily decisions influenced by interaction between decisionmakers and their underlings. We argued that female supervisees have better opportunities to benefit from network contacts and to establish their claims in negotiations and conflicts over scarce resources in organizations in which relatively many of the decision-makers are women. Female subordinates should be advantaged when other women are an integral part of the organization's power structure, because interaction is facilitated by gender similarity between actors.

These two perspectives can be analytically translated into the question what hierarchical proximity vs. distance between decision-makers and subordinates means for organizational processes generating gender wage inequality. The data material enabled us to empirically distinguish between the sex composition among managers (i.e., high-level decision-makers) and among supervisors (i.e., lower-level decision-makers). We found that the gender wage gap for blue-collar workers seems to be more affected by the sex composition among close supervisors than by the sex composition among more hierarchically distant managers. On basis of this single result, however, we are reluctant to dismiss the hypothesis derived from well-founded structural theories stating that 
general policies adopted at higher organizational levels are important mechanisms behind gender inequality in the labor market. But the idea that a substantial fraction of the gender wage gap has its explanation in gendered daily interactions and decisionmaking at lower hierarchical levels within establishments has no doubt survived an initial empirical inquiry. Important tasks for future research lies in trying to shed more light on this issue and in corroborating our main results in an international context. Although confined to a single country, the findings are no doubt suggestive. The contention that female employees in general benefit from working in establishments with a relatively strong female representation in power structures received strong support. This is, we believe, an important contribution to the analysis of mechanisms generating gender inequality in the labor market. 
TABLE 1. HLM-coefficients from regression models of between-organizational variance in gender wage gaps predicted by the proportion of male managers and supervisors, the proportion of female employees, industry, and human capital. Blue-collar employees and white-collar employees separately. Robust standard errors in parentheses.

\begin{tabular}{|c|c|c|c|c|c|c|}
\hline & \multicolumn{3}{|c|}{ Blue-collar employees } & \multicolumn{3}{|c|}{ White-collar employees } \\
\hline & MODEL 1 & MODEL 2 & MODEL 3 & MODEL 4 & MODEL 5 & MODEL 6 \\
\hline $\begin{array}{l}\text { INDIVIDUAL-LEVEL, FIXED EFFECTS: } \\
\text { Years of education }\end{array}$ & $\begin{array}{c}0.0023^{\text {*** }} \\
(0.0005)\end{array}$ & $\begin{array}{c}0.0023^{\text {*** }} \\
(0.0005)\end{array}$ & $\begin{array}{c}0.0023^{\text {*** }} \\
(0.0005)\end{array}$ & $\begin{array}{c}0.0516^{* * *} \\
(0.0016)\end{array}$ & $\begin{array}{c}0.0516^{* * *} \\
(0.0016)\end{array}$ & $\begin{array}{c}0.0516^{\text {*** }} \\
(0.0016)\end{array}$ \\
\hline Experience & $\begin{array}{l}0.0125^{* *} \\
(0.0010)\end{array}$ & $\begin{array}{l}0.0125^{* *} \\
(0.0010)\end{array}$ & $(0.0010)$ & $\begin{array}{l}0.0293^{* *} \\
(0.0012)\end{array}$ & $\begin{array}{l}0.0294^{* *} \\
(0.0012)\end{array}$ & $\begin{array}{l}0.0295^{* *} \\
0.0012\end{array}$ \\
\hline Experience squared/100 & $\begin{array}{l}-0.0298^{* *} \\
(0.0022)\end{array}$ & $\begin{array}{l}-0.0298^{* *} \\
(0.0021)\end{array}$ & $\begin{array}{l}-0.0299^{* *} \\
(0.0022)\end{array}$ & $\begin{array}{c}-0.0426^{* *} \\
0.0023)\end{array}$ & $\begin{array}{c}-0.0426^{* *} \\
0.0024)\end{array}$ & $\begin{array}{l}-0.0426^{* *} \\
(0.0024)\end{array}$ \\
\hline Seniority & $\begin{array}{c}0.0091^{* * *} \\
(0.0011)\end{array}$ & $\begin{array}{l}0.0091^{* *} \\
(0.0011)\end{array}$ & $\begin{array}{l}0.0091^{* *} \\
(0.0011)\end{array}$ & $\begin{array}{l}-0.0009 \\
(0.0008)\end{array}$ & $\begin{array}{l}-0.0009 \\
(0.0008)\end{array}$ & $\begin{array}{l}-0.0009 \\
(0.0008)\end{array}$ \\
\hline ESTABLISHMENT-LEVEL EFFECTS: & & & & & & \\
\hline Intercept & $\begin{array}{r}9.5647 \\
(0.0072)\end{array}$ & $\begin{array}{c}9.3833 \\
(0.0355)\end{array}$ & $\begin{array}{c}9.4952 \\
(0.0473)\end{array}$ & $\begin{array}{c}9.8824 \\
(0.0058)\end{array}$ & $\begin{array}{c}9.8283 \\
(0.0324)\end{array}$ & $\begin{array}{l}9.8143 \\
0.0338\end{array}$ \\
\hline Proportion of male managers and supervisors & & $\begin{array}{l}0.2017^{* *} \\
(0.0391)\end{array}$ & $\begin{array}{c}0.0357 \\
(0.0484)\end{array}$ & & $\begin{array}{c}0.0610 \\
(0.0353)\end{array}$ & $\begin{array}{c}0.0637 \\
(0.0350)\end{array}$ \\
\hline Lnsize & & & $\begin{array}{l}0.0347^{* *} \\
(0.0053)\end{array}$ & & & $\begin{array}{l}0.0124^{* *} \\
(0.0031)\end{array}$ \\
\hline Proportion of female employees & & & $\begin{array}{l}-0.1444^{* *} \\
(0.0253)\end{array}$ & & & $\begin{array}{l}-0.0092 \\
(0.0284)\end{array}$ \\
\hline Control for industry & No & No & Yes & No & No & Yes \\
\hline Gender wage gap & $\begin{array}{l}-0.0744^{* *} \\
(0.0039)\end{array}$ & $\begin{array}{c}0.0245 \\
(0.0195)\end{array}$ & $\begin{array}{c}0.0333 \\
(0.0201)\end{array}$ & $\begin{array}{l}-0.1718^{* *} \\
(0.0043)\end{array}$ & $\begin{array}{l}-0.0696^{* *} \\
(0.0224)\end{array}$ & $\begin{array}{l}-0.0718^{* *} \\
(0.0228)\end{array}$ \\
\hline $\begin{array}{l}\text { Proportion of male managers and supervisors* } \\
\text { gender wage gap }\end{array}$ & & $\begin{array}{l}-0.1096^{* *} \\
(0.0214)\end{array}$ & $\begin{array}{l}-0.1120^{* *} \\
(0.0220)\end{array}$ & & $\begin{array}{l}-0.1171^{* *} \\
(0.0253)\end{array}$ & $\begin{array}{l}-0.1178^{* *} \\
(0.0256)\end{array}$ \\
\hline RANDOM EFFECTS: & & & & & & \\
\hline Variance in intercepts $U_{0 j}$ & 0.0152 & 0.0139 & 0.0094 & 0.0146 & 0.0146 & 0.0139 \\
\hline Variance in gender wage gap $U_{1 j}$ & 0.0026 & 0.0024 & 0.0025 & 0.0057 & 0.0051 & 0.0052 \\
\hline Individuatlevel variance $R_{i j}$ & 0.0205 & 0.0205 & 0.0205 & 0.0412 & 0.0412 & 0.0412 \\
\hline Number of organizations & 317 & 317 & 317 & 546 & 546 & 546 \\
\hline Number of individuals & 82190 & 82190 & 82190 & 74960 & 74960 & 74960 \\
\hline
\end{tabular}


$\stackrel{*}{\mathrm{p}} \leq 0.05 \quad{ }^{* *} \mathrm{p} \leq 0.01$

TABLE 2. HLM-coefficients from regression models of between-organizational variance in gender wage gaps predicted by the proportion of male managers and supervisors, the proportion of female employees, industry, human capital, and average grades. Blue-collar employees and white-collar employees separately. Robust standard errors in parentheses.

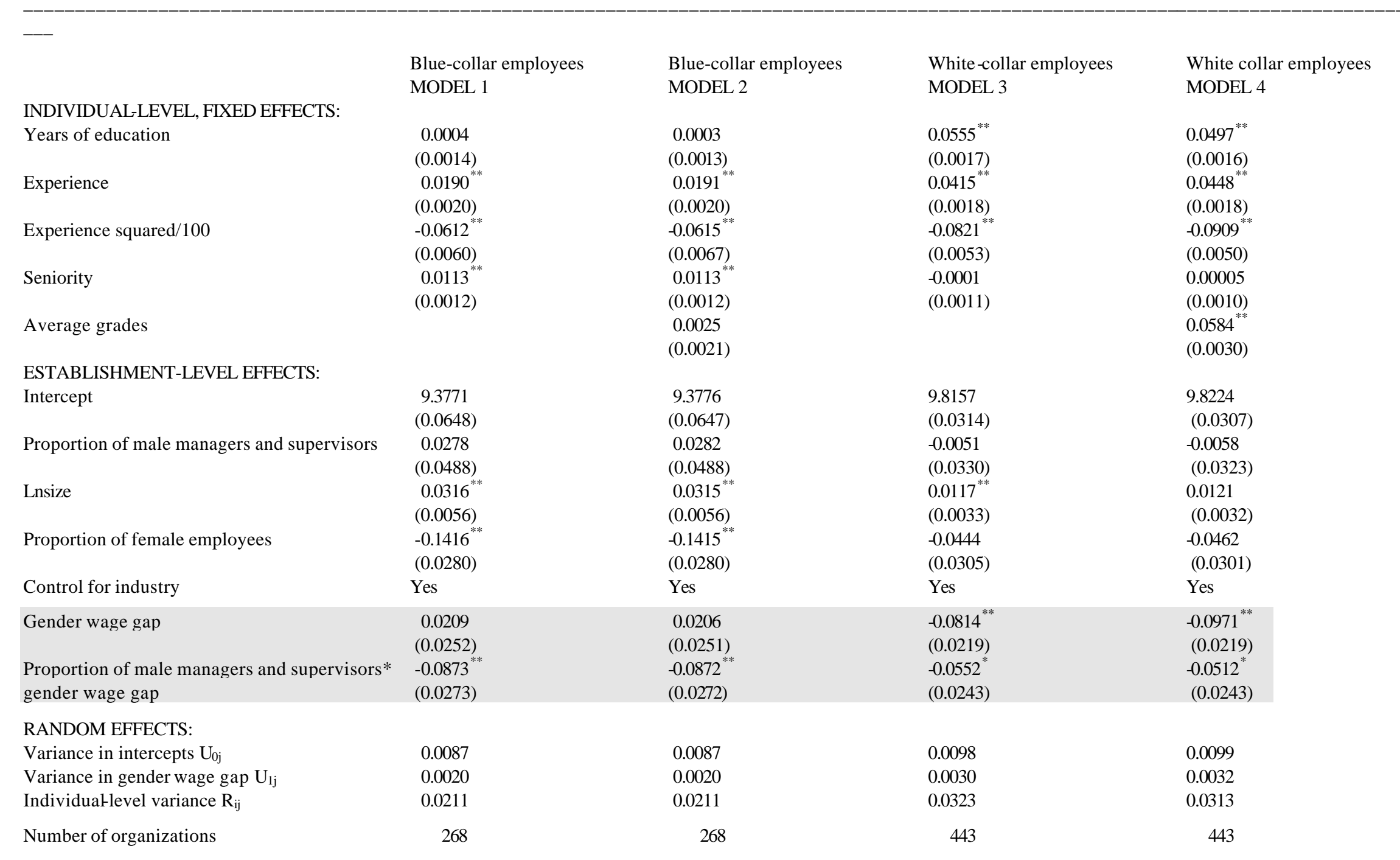


Number of individuals

p $\leq 0.05$ ** $\mathrm{p} \leq 0.01$ 
TABLE 3. HLM-coefficients from regression mo dels of between-organizational variance in gender wage gaps predicted by the proportion of male managers and male supervisors, the proportion of female employees, industry, and human capital. Blue-collar employees and white-collar employees separately. Robust standard errors in parentheses.

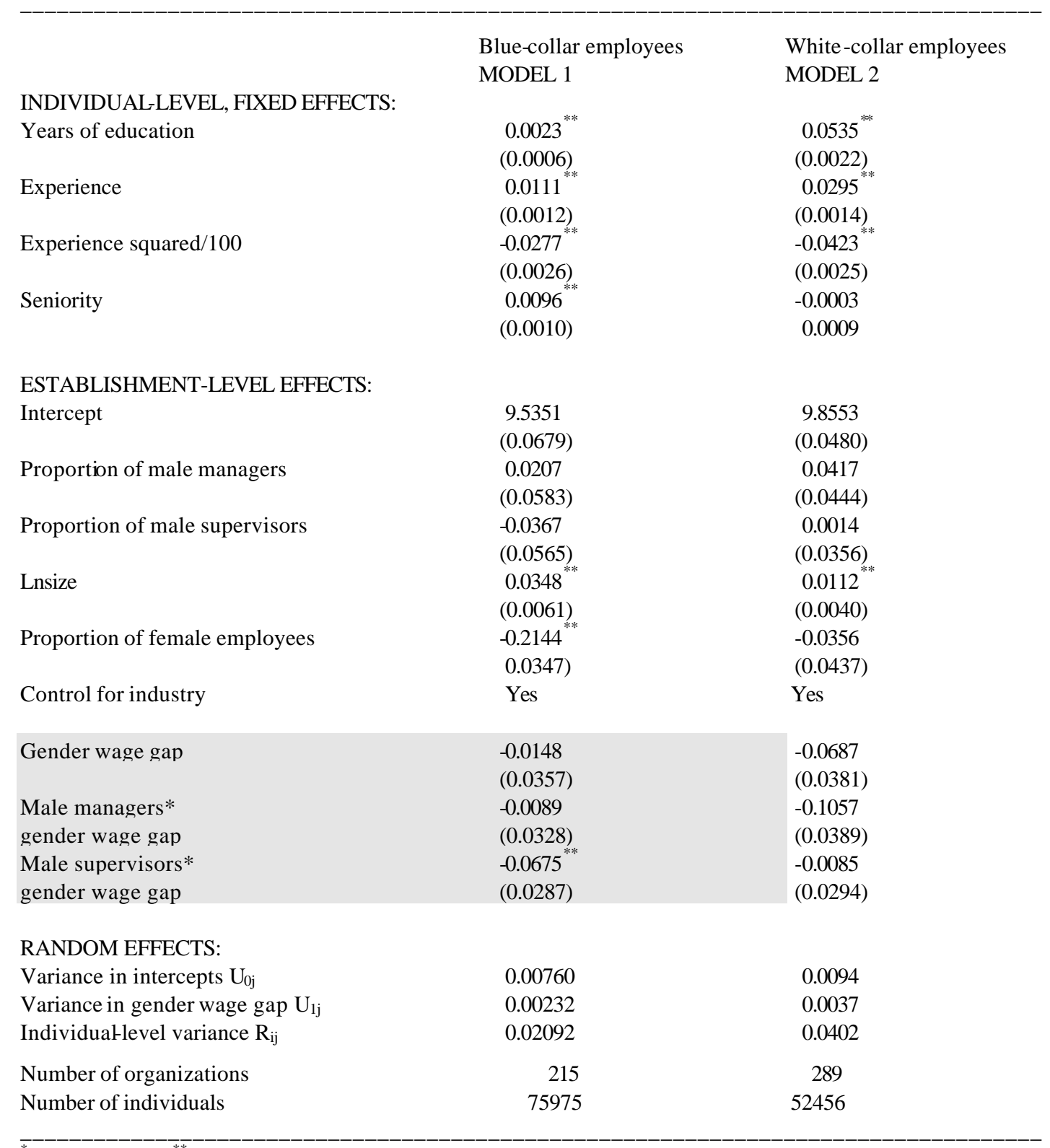

${ }^{*} \mathrm{p} \leq 0.05 \quad{ }^{* *} \mathrm{p} \leq 0.01$ 


\section{REFERENCES}

Acker, J.

1989 Doing comparable worth: gender, class and pay equity. Philadelphia: Temple University Press.

Acker, J.

1990 "Hierarchies, Jobs, Bodies: A Theory of Gendered Organizations", Gender and Society, 4: 139-158.

Acker, J.

1991 “Thinking about Wages: The Gendered Wage Gap in Swedish Banks.” Gender and Society, 5: 390-407.

Acker, J.

1992 "Gendered Institutions: From Sex Roles to Gendered Institutions."

Contemporary Sociology, 21:565-568.

Baron, J. N.

1991 "Organizational Evidence of Ascription in Labor Markets.” In R. R.Cornwall and P. V. Wunnava (eds.), New Approaches to Economic and Social Analyses of Discrimination. New York: Prager Publishers.

Baron, J. N. and W. T. Bielby

1980 "Bringing the Firm Back in: Stratification, Segmentation, and the Organization of Work." American Sociological Review, 45: 737-765.

Baron, J. N., B. S. Mittman, and A. E. Newman

1991 "Targets of Opportunity: Organizational and Environmental Determinants of

Gender Integration within the California Civil Se rvice, 1979 - 1985." American Journal of Sociology, 96: 1362-1401.

Barth, E. and J. Zweimuller

1995 "Relative Wages under Decentralized and Corporatist Bargaining Systems." Scandinavian Journal of Economics, 97: 368-384.

Bayard, K., J. Hellerstein, D. Neumark, and K. Troske

1999 "New Evidence on Sex Segregation and Sex Differences in Wages from Matched Employee-Employer Data.” NBER Working Paper Series. Cambridge, Mass.: National Bureau of Economic Research.

Bielby, W. T.

1987 "Modern Prejudice and Ins titutional Barriers to Equal Employment Opportunity for Minorities." Journal of Social Issues, 43: 79-84.

Bielby, W. T. and J. N. Baron 
1986 "Men and Women at Work: Sex Segregation and Statistical Discrimination." American Journal of Sociology, 91: 759-797. 
Blalock, H. M.

1967 Toward a Theory of Minority Group Relations. New York: John Wiley.

Blau, F. D., M. A. Ferber, and A. E. Winkler

1998 The Economics of Women, Men, and Work. Englewood Cliffs, New Jersey: Prentice Hall.

Blau, F. D. and L. M. Kahn

1992 "The Gender Earnings Gap: Learning from International Comparisons."

American Economic Review Papers and Proceedings,

82: 533-538.

Blau, F. D. and L. M. Kahn

1996 "International Differences in Male Wage Inequality.” Journal of Political Economy, 104: 791-836.

Borjas, G. J.

1996 Labor Economics. New York: McGraw-Hill International Editions.

Boxman, A. W., P. M. De Graaf, and H. D. Flap

1991 "The Impact of Social and Human Capital on the Income Attainment of Dutch Managers." Social Networks, 13: 51-73.

Bridges, W. P.

1989 "Markets in Hierarchies: Organizational and Market Influences on Gender Inequality in a State Pay System.” American Journal of Sociology, 95: 616-658.

Bridges, W. P. and W. J. Villemez

1986 "Informal Hiring and Income in the Labor Market." American Sociological Review, 51: 574-582.

Bryk, A. S. and S. W. Raudenbush

1992 Hierarchical Linear Models. Applications and Data Analysis Methods. Newbury Park: Sage.

Burt, R. S.

1995 Structural Holes: The Social Structure of Competition. Cambridge: Harvard University Press.

Byrne, D.

1971 The Attraction Paradigm. New York: Academic Press.

Carrington, W. J. and K. R. Troske

1998 "Sex Segregation in U.S. Manufacturing." Industrial and Labor Relations, 51: 445-464. 
Cohen, L. E., J. P. Broschak, and H. A. Haveman

1998 "And then there were more? The Effect of Organizational Sex Composition on the Hiring and Promotion of Managers." American Sociological Review, 63: 711-727.

DiPrete, T. A. and W. T. Soule

1988 "Gender and Promotion in Segmented Job Ladder Systems", American Sociological Review, 53: 26-40.

Edin, P. A. and B. Holmlund

1995 "The Swedish Wage Structure: The Rise and Fall of Solidarity Wage-Policy." In R. B. Freeman and L. F. Katz (eds.), Differences and Changes in Wage Structures. Chicago: University of Chicago Press and National Bureau of Economic Research.

Edin, P. A. and R. Topel

1997 "Wage Policy and Restructuring: The Swedish labor market since 1960." In R. B. Freeman, R. Topel, and B. Swedenborg (eds.), The Welfare State in Transition. Reforming the Swedish Model. Chicago: University of Chicago Press and National Bureau of Economic Research.

Elliott, R. F. and K. A. Bender

1997 "Decentralization and Pay Reform in Central Government: A Study of Three Countries.” British Journal of Industrial Relations, 35: 447-475.

Ely, R.

1995 "The Power in Demography: Women's Social Constructions of Gender Identity at Work." Academy of Management Journal, 38: 589-634.

le Grand, C., and M. Tåhlin

1998 “Job Mobility and Earnings Growth", Working Paper 9/1998, Stockholm:

Swedish Institute for Social Research.

le Grand, C., R. Szulkin, and M. Tåhlin

1994 "Organizational Structures and Job Rewards in Sweden." Acta Sociologica, 37: 231-252.

le Grand, C., R., Szulkin, and M. Tåhlin

1995 "Why Do Some Employers Pay More than Others? Earnings Variation Across Establishments in Sweden", Research in Social Stratification and Mobility, 14: 265-296.

Granovetter, M.

1988 "The Sociological and Economic Approaches to Labor Market Analysis: A Social Structural View." In G. Farkas and P. England (eds.), Industries, Firms, and Jobs. New York: Plenum Press. 
Groshen, E. L.

1991a "The Structure of the Female/Male Wage Differential: Is It Who You Are, What You Do, or Where You Work?" Journal of Human Resources, 26: 457-472.

Groshen, E. L.

1991b "Five Reasons Why Wages Vary Among Employers.” Industrial Relations, 30: 350-381.

Hammond, S. and R. Harbridge

1995 "Women and Enterprise Bargaining: The New Zealand Experience of Labour Market Deregulation." Journal of Industrial Relations, 37: 359-376.

Hedström, P.

forthc. "Rational Choice and Social Structure: On Rational-Choice Theorizing in Sociology." In B. Wittrock (ed.), Social Theory and Human Agency. London: Sage.

Hibbs, D. A.

1991 "Market Forces, Trade Union Ideology and Trends in Swedish Wage Dispersion." Acta Sociologica, 34: 89-102.

Hultin, M. and R. Szulkin

1999 "Wages and Unequal Access to Organizational Power: An Empirical Test of Gender Discrimination.” Administrative Science Quarterly, 44: 453-472.

Kanter, R. M.

1977 Men and Women of the Corporation. New York: Basic Books.

Kim, M.

1989 "Gender Bias in Compensation Structures: A Case Study of Its Historical Basis and Persistence." Journal of Social Issues, 45: 39-50.

Lin, N.

1999 "Social Networks and Status Attainment." Annual Review of Sociology, 25: 467-487.

McPherson, J. M. and L. Smith-Lovin

1987 "Homophily in Voluntary Organizations: Status Distance and the Composition of Face-to-Face Groups.” American Sociological Review, 52: 370-379.

Marini, M.

1989 "Sex Differences in Earnings in the United States." Annual Review of Sociology, 15: 343-380.

Milkman, R. 
1987 Gender at Work. Urbana: University of Illinois Press.

Pfeffer, J.

1989 "A Political Perspective on Careers: Interests, Networks, and Environments." In M. B. Arthur, D. T. Hall and B. S. Lawrence (eds.), Handbook of Career Theory. Cambridge: Cambridge University Press.

Pfeffer, J. and A. Davis-Blake

1987 "The Effect of the Proportion of Women on Salaries: The Case of College Administrators." Administrative Science Quarterly, 32: 1-24. 
Pfeffer, J. and G. R. Salancik

1978 The external control of organizations: a resource dependence perspective. New York: Harper and Row.

Reskin, B. F.

1988 "Bringing the Men Back in: Sex Differentiation and the Devaluation of Women's Work." Gender and Society, 2: 58-81.

Reskin, B. F., D. M. McBrier, and J. A. Kmec

1999 "The Determinants and Consequences of Workplace Sex and Race Composition.” Annual Review of Sociology, 25: 335-361.

Reskin, B.F. and D. B. McBrier

2000 "Why Not Ascription? Organizations' Employment of Male and Female Managers", American Sociological Review, 65: 210-233.

Reskin, B. and I. Padavic

1988 “Supervisors as Gatekeepers: Male Supervisors' Response to Women's Integration in Plant Jobs." Social Problems 35: 536-550.

Reskin, B. F. and I. Padavic

1994 Women and Men at Work. Thousand Oaks, California: Pine Forge Press.

Rosenfeld, R. A. and A. L. Kalleberg

1990 "A Cross-National Comparison of the Gender Gap in Income." American

Journal of Sociology, 96: 69-106.

Shenhav, Y. and Y. Haberfeld

1992 "Organizational Demography and Inequality." Social Forces, 71: 123-143.

Simon, C. J. and J. T. Warner

1992 "Matchmaker, Matchmaker: The Effect of Old-Boy Networks on Job Match Quality, Earnings, and Tenure.” Journal of Labor

Economics, 10: 306-329.

Statistics Sweden

1992 "Swedish Standard Industrial Classification 1992", Reports on Statistical Co ordination 1992:6. Stockholm: Statistics Sweden.

Stolzenberg, R. M.

1978 "Bringing the Boss Back In: Employer Size, Employee Schooling, and

Socioeconomic Achievement", American Sociological Review, 43: 813-828.

Tajfel, H.

1982 “Social Psychology of Intergroup Relations.” Annual Review of Sociology, 33: 1-39. 
Tomaskovic-Devey, D.

1993 Gender and Racial Inequality at Work: The Sources and Consequences of Job Segregation. Ithaca, N.Y.: ILR Press.

Topel, R.

1991 "Specific Capital, Mobility, and Wages: Wages Rise with Job Seniority", Journal of Political Economy, 99: 145-176.

Treiman, D. J. and H. I. Hartmann

1981 Women, Work, and Wages. Washington D.C.: National Academy Press. 


\section{APPENDIX}

TABLE A1: Descriptives for individual-level and organizational-level variables. Blue-collar employees only.

\begin{tabular}{|c|c|c|c|c|c|}
\hline Variable & Mean & Std. deviation & Min. value & Max. value & N. \\
\hline Monthly wages, SEK & 15208.67 & 3110.40 & 3671.00 & 41009 & 82190 \\
\hline Experience & 17.89 & 10.52 & 0.00 & 36.00 & 82190 \\
\hline Seniority & 6.56 & 3.25 & 0.50 & 9.50 & 82190 \\
\hline Educational years & 10.23 & 1.87 & 7.4 & 20.0 & 82190 \\
\hline $\begin{array}{l}\text { Proportion of male } \\
\text { managers and } \\
\text { supervisors }\end{array}$ & 0.89 & 0.19 & 0.00 & 1.00 & 317 \\
\hline $\begin{array}{l}\text { Proportion of female blue- } \\
\text { collar employees }\end{array}$ & 0.33 & 0.25 & 0.01 & 0.94 & 317 \\
\hline Organizational size & 468 & 792.71 & 8 & 7005 & 317 \\
\hline
\end{tabular}

TABLE A2: Descriptives for individual-level and organizational-level variables. White-collar employees only.

\begin{tabular}{|c|c|c|c|c|c|}
\hline Variable & Mean & Std. deviation & Min. value & Max. value & N. \\
\hline Monthly wages, SEK & 19767.16 & 7223.16 & 5450.00 & 343986.80 & 74960 \\
\hline Experience & 21.56 & 9.77 & 0.00 & 36.00 & 74960 \\
\hline Seniority & 5.27 & 3.50 & 0.50 & 9.50 & 74960 \\
\hline Educational years & 12.96 & 2.87 & 7.40 & 20.00 & 74960 \\
\hline $\begin{array}{l}\text { Proportion of male } \\
\text { managers and } \\
\text { supervisors }\end{array}$ & 0.87 & 0.22 & 0.00 & 1.00 & 546 \\
\hline $\begin{array}{l}\text { Proportion of female } \\
\text { white-collar employees }\end{array}$ & 0.44 & 0.19 & 0.01 & 0.98 & 546 \\
\hline Organizational size & 307 & 638.63 & 3 & 7005 & 546 \\
\hline
\end{tabular}


TABLE A3. HLM-coefficients from regression models of between-organizational variance in gender wage gaps predicted by the proportion of male managers and supervisors, the proportion of female employees, industry, human capital, and skilllevel. White-collar employees only. Robust standard errors in parentheses.

\begin{tabular}{|c|c|}
\hline & $\begin{array}{l}\text { White collar employees } \\
\text { MODEL } 1\end{array}$ \\
\hline \multicolumn{2}{|l|}{ INDIVIDUAL-LEVEL, FIXED EFFECTS: } \\
\hline \multirow[t]{2}{*}{ Years of education } & $0.0368^{* *}$ \\
\hline & $(0.0014)$ \\
\hline \multirow[t]{2}{*}{ Experience } & $0.0269^{* *}$ \\
\hline & $(0.0008)$ \\
\hline \multirow[t]{2}{*}{ Experience squared } & $-0.0398^{* *}$ \\
\hline & $(0.0017)$ \\
\hline \multirow[t]{2}{*}{ Seniority } & -0.0013 \\
\hline & $(0.0008)$ \\
\hline \multirow[t]{2}{*}{ Skill level 2} & $0.0854^{* * *}$ \\
\hline & $(0.0066$ \\
\hline \multirow[t]{2}{*}{ Skill level 3} & 0.2514 \\
\hline & $(0.0102)$ \\
\hline \multicolumn{2}{|l|}{ ESTABLISHMENT-LEVEL EFFECTS: } \\
\hline \multirow[t]{2}{*}{ Intercept } & 9.7444 \\
\hline & $(0.0282)$ \\
\hline \multirow[t]{2}{*}{ Proportion of male managers and supervisors } & 0.0238 \\
\hline & $(0.0285)$ \\
\hline \multirow[t]{2}{*}{ Lnsize } & $0.0062^{* * *}$ \\
\hline & $(0.0029)$ \\
\hline \multirow[t]{2}{*}{ Proportion of female employees } & -0.0209 \\
\hline & $(0.0277)$ \\
\hline Control for industry & Yes \\
\hline \multirow[t]{2}{*}{ Gender wage gap } & $-0.0831^{* *}$ \\
\hline & $(0.0199)$ \\
\hline Proportion of male managers & $-0.0735^{* *}$ \\
\hline and supervisors*gender wage gap & $(0.0226)$ \\
\hline \multicolumn{2}{|l|}{ RANDOM EFFECTS: } \\
\hline Variance in intercepts $\mathrm{U}_{0 \mathrm{j}}$ & 0.0110 \\
\hline Variance in genderwage gap $U_{1 j}$ & 0.0041 \\
\hline Individuatlevel variance $R_{i j}$ & 0.0357 \\
\hline Number of organizations & 546 \\
\hline Number of individuals & 73057 \\
\hline
\end{tabular}

${ }^{*} \mathrm{p} \leq 0.05 \quad{ }^{* *} \mathrm{p} \leq 0.01$ 
${ }^{1}$ Borjas (1996) has traced the oldest documented and quantified gender wage differential to the Old Testament: The Lord spoke to Moses and said, Speak to the Israelites in these words. When a man makes a special vow to the Lord which requires your valuation of living persons, a male between twenty and fifty years old shall be valued at fifty silver shekels, that is shekels by the sacred standard. If it is a female, she shall be valued at thirty shekels (Leviticus 27: 1-4). Hence, the female-male wage ratio (with a rough control for age) prescribed by the Lord is 0.6. Our interpretation of the Biblical quotation is that it gives the first known illustration of the negative influence on women's wages of the overrepresentation of men among organizational decision-makers.

${ }^{2}$ The heading paraphrases Stolzenberg's article "Bringing the Boss Back In” (1978).

${ }^{3}$ The opposite majority power argument (Blalock 1967) suggests that minority groups that grow numerically pose a threat to majority groups, who in turn react by triggering off discriminatory practices against minority group members.

${ }^{4}$ The probability of selection in this survey was proportionate to the number of employees in the establishment. An establishment is defined as a workplace that has one single address and one single employer. For a presentation of the Swedish Establishment Survey, see le Grand, Szulkin and Tåhlin (1995).

${ }^{5}$ This measure does not allow us to distinguish between income from wages and income from other sources, such as various public welfare programs. However, our measure is probably more reliable than the often used indirect measure that estimates experience by subtracting from age the number of years of schooling together with the age at which one enters compulsory school. Such a measure tends to overestimate labor market experience for women who have interrupted their labor market careers for child-care.

${ }^{6}$ The classification of industries is "Standard för svensk näringsgrensindelning (SNI) 1992" (see Statistics Sweden 1992:6). This classification follows the EU "Nomenclature Générale des Activités dans les Communautés Européennes". We have collapsed industries into eleven broad categories, namely engineering; other manufacturing; construction; trade, hotel, and restaurant; transportation, post, and telecommunication; financial business and related services; other business services; other private services; health care; research and development; and culture, sport, recreation, and voluntary organizations.

${ }^{7}$ The first equation in the level- 2 model is then expanded in the following way: $\mathrm{B}_{0 \mathrm{j}}=\mathrm{G}_{00}+\mathrm{G}_{01} *$ PROPMALEBOSS $_{\mathrm{j}}+\mathrm{G}_{02} *$ PROPWOMEN $_{\mathrm{j}}+\mathrm{G}_{03} * \ln \mathrm{SIZE}_{\mathrm{j}}+\mathrm{G}_{\mathrm{oi}} \sum$ IND $_{\mathrm{i}}+\mathrm{U}_{0 \mathrm{j}}$. 
${ }^{8}$ Another possible selection bias is accounted for in the first category of models, in which we allow the intercepts for organizational mean wage levels to vary. If highly productive female (or male) employees were systematically allocated to certain organizations, these organizations should be characterized by high wage levels compared to organizations with a more normal distribution of talent among employees.

${ }^{9}$ Overall, the effects of the human capital variables on earnings are the expected. However, one should notice that the effect of seniority on earnings is weak and negative for white-collar employees. The potential positive effect of seniority on wages may be counteracted by the positive effect of external job shifts for this category of employees. Without access to data on effects of external shifts on earnings, we cannot estimate seniority effects in a correct way (Topel 1991, le Grand and Tålin 1998).

${ }^{10}$ The estimated effects of the proportion of male decision-makers on the gender wage gap can be calculated by substituting values from Model 2 and Model 5 into equation 3 for the level-2 Model.

${ }^{11}$ It should be mentioned that we have performed a formal statistical test to prove that the negative effect on female employees' relative wages is stronger in absolute terms than is the positive effect on overall mean wages of the proportion of male managers and supervisors in establishments. It turned out that the sums of the former effect and the latter effect for blue-collar workers $(-0.112+0.036)$ and for white-collar workers $(-0.118+0.064)$ are significantly different from zero. Furthermore, in order to scrutinize if the main results generated by Models 3 and 6 in Table 1 could be driven by a few influential cases, we let HLM create a residual file enabling detection of outlying units. We detected 4 suspicious cases for blue-collar employees and 14 for white-collar employees. The main results were largely unaltered when we reran the models without these cases.

${ }^{12}$ The formal notation for this expanded model is the following:

Level-1: $\quad \operatorname{lnwage}_{\mathrm{ij}}=\mathrm{B}_{0 \mathrm{j}}+\mathrm{B}_{\mathrm{jj}} * \mathrm{WOM}_{\mathrm{ij}}+\mathrm{B}_{2 \mathrm{j}} * \mathrm{EXP}_{\mathrm{ij}}+\mathrm{B}_{3 \mathrm{j}} * \mathrm{EXPSQ}_{\mathrm{ij}}+\mathrm{B}_{4 \mathrm{j}} * \mathrm{SEN}_{\mathrm{ij}}+\mathrm{B}_{5 \mathrm{j}} * \mathrm{EDUC}_{\mathrm{ij}}+\mathrm{R}_{\mathrm{ij}}$

Level-2: $\quad \mathrm{B}_{0 \mathrm{j}}=\mathrm{G}_{00}+\mathrm{G}_{01} *$ PROPMALEBOSS $_{\mathrm{j}}+\mathrm{G}_{02} *$ PROPWOMEN $_{\mathrm{j}}+\mathrm{G}_{03} * \ln \ln _{\mathrm{Z}} \mathrm{E}_{\mathrm{j}}+\mathrm{G}_{\mathrm{oi}} \sum$ IND $_{\mathrm{i}}+\mathrm{U}_{0 \mathrm{j}}$

$\mathrm{B}_{1 \mathrm{j}}=\mathrm{G}_{0}+\mathrm{G}_{1} *$ PROPMALEBOSS $_{\mathrm{j}}+\mathrm{U}_{1 \mathrm{j}}$

$\mathrm{B}_{2}=\mathrm{G}_{20}+\mathrm{U}_{2 \mathrm{j}}$

$\mathrm{B}_{3}=\mathrm{G}_{30}+\mathrm{U}_{3 \mathrm{j}}$

$\mathrm{B}_{4}=\mathrm{G}_{40}+\mathrm{U}_{4 \mathrm{j}}$

$\mathrm{B}_{5}=\mathrm{G}_{50}+\mathrm{U}_{5 \mathrm{j}}$

${ }^{13}$ This rather substantial reduction of the number of organizations has to do with the fact that a certain fraction of mainly smaller establishments employs only or almost only relatively old individuals for whom we have no data on average grades. Organizations are excluded from the analyses also in cases when they employ people for which there are data on average grades, but when the gender composition among these employees is totally 
skewed (i.e., when 100 percent of them are men or women, respectively). Quite evidently, the probability for exclusion on these grounds is greater the smaller the number of employees within an establishment. 